\title{
Ent-kaurane Diterpenoid Glycosides from the Leaves of Cussonia racemosa, a Malagasy Endemic Plant
}

\author{
Liva Rakotondraibe Romuald HarinANTENAINA, Ryoji KASAI, and Kazuo YAMASAKI* \\ Institute of Pharmaceutical Sciences, Faculty of Medicine, Hiroshima University, 1-2-3 Kasumi, Minami-ku, Hiroshima \\ 734-8551, Japan. Received October 1, 2001; accepted November 9, 2001
}

\begin{abstract}
Six new ent-kaurane diterpenoid glycosides, cussoracosides A (3), B (4), C (5), D (6), E (7), and F (8) were isolated from the dried leaves of Cussonia racemosa, along with two known compounds identified as $\beta$-D-glucopyranosyl ent-16 $\beta, 17$-dihydroxykauran-19-oate (1) and paniculoside IV (2). The structures of these new compounds were deduced on the basis of chemical and spectroscopic evidence.
\end{abstract}

Key words Cussonia racemosa; Araliaceae; cussoracoside; Kaurane-type diterpenoid glycoside; sweet glycoside

The genus Cussonia, called "umbrella trees" (Araliaceae), represented by 40 species, has its center of distribution in tropical areas in South Africa and in Madagascar. ${ }^{1)}$ Some species have been used to treat acne, diarrhea, syphilis, mental diseases, malaria, and rheumatism and as antispasmodic. ${ }^{2,3)}$ The presence of $\mathrm{C}_{18}$-polyacetylenes, triterpenoids, and triterpenoid saponins with D-glucose, L-rhamnose, L-arabinose, and D-xylose as sugar components has been reported in some species of this genus. ${ }^{3-7)}$ In our continuing search for novel biologically active compounds from Malagasy endemic plants, we examined the leaves of Cussonia racemosa, widely distributed in central and eastern of Madagascar. No chemical investigation has been carried out in this species. The present study deals with the isolation and structure elucidation of eight ent-kaurane diterpenoid glycosides from the leaves of the plant.

\section{Results and Discussion}

The methanolic extract of the dried leaves of C. racemosa on chromatographic purification followed by systematic HPLC separation (see experimental) led to the isolation of eight ent-kaurane type diterpenes $(\mathbf{1}-\mathbf{8})$. Two of them were identified as the known ent-kaurane derivatives $\beta$-D-glucopyranosyl ent-16 $\beta, 17$-dihydroxykauran-19-oate $(\mathbf{1})^{8)}$ and paniculoside IV (2) ${ }^{9,10)}$ by comparison of their spectral data with the reported data.

The molecular formula of cussoracoside A (3) was determined to be $\mathrm{C}_{26} \mathrm{H}_{42} \mathrm{O}_{9}$ by NMR and high resolution (HR)FAB mass spectrometry. On alkaline hydrolysis, 3 afforded 1,6-anhydroglucose, suggesting the presence of an esterlinked glucose. ${ }^{11)}$ Inspection of the ${ }^{1} \mathrm{H}$ - and ${ }^{13} \mathrm{C}-\mathrm{NMR}$ spectra allowed us to propose that the aglycone of $\mathbf{3}$ is a kaurane diterpenoid with a carboxyl group $\left(\delta_{\mathrm{C}} 177.7\right)$, a tertiary hydroxyl group $\left(\delta_{\mathrm{C}} 81.6\right)$, and a primary hydroxyl group $\left[\delta_{\mathrm{C}}\right.$ $66.4, \delta_{\mathrm{H}} 4.01(1 \mathrm{H}, \mathrm{d}, J=10.0 \mathrm{~Hz}), \delta_{\mathrm{H}} 4.10(1 \mathrm{H}, \mathrm{d}, J=10.0$ $\mathrm{Hz})$. The ${ }^{13} \mathrm{C}$-NMR spectrum of $\mathbf{3}$ was very similar to that of ent-kaurane glycoside 2 except for the signals due to the Aring, suggesting that $\mathbf{3}$ is a C-4 epimer of $\mathbf{2}$ with respect to the stereochemistry of C-4, i.e. the carboxyl group of $\mathbf{3}$ is equatorial. The orientation was confirmed by the observation of an nuclear Overhauser effect (NOE) between the two methyl groups ( $\delta 0.98, \delta 1.32)$ on $\mathrm{C}-4$ and $\mathrm{C}-10$ of $\mathbf{3}$. From this evidence, the structure of $\mathbf{3}$ was assigned as shown.

Compounds 4 (cussoracoside $\mathrm{B}, \mathrm{C}_{31} \mathrm{H}_{48} \mathrm{O}_{12}$ bitter taste), and 5 (cussoracoside $\mathrm{C}, \mathrm{C}_{32} \mathrm{H}_{50} \mathrm{O}_{13}$ sweet taste) yielded a common aglycone 4a upon enzymatic hydrolysis, while glucose and apiose were obtained from $\mathbf{4}$ and glucose from 5 by acid hydrolysis. Inspection of the ${ }^{1} \mathrm{H}$ - and ${ }^{13} \mathrm{C}$-NMR spectra suggested that 4a is a kaurane diterpenoid with an exocyclic methylene $\left[\delta_{\mathrm{C}} 106.4,150.9, \delta_{\mathrm{H}} 5.19(1 \mathrm{H}, \mathrm{brs}), 4.98(1 \mathrm{H}\right.$, brs)], a secondary hydroxyl $\left[\delta_{\mathrm{C}} 71.2, \delta_{\mathrm{H}} 4.00(1 \mathrm{H}\right.$, ddd, $J=11.5,6.0,3.1 \mathrm{~Hz})$, and a carboxyl $\left(\delta_{\mathrm{C}} 180.0\right)$ group. The allocation of the double bond at $\mathrm{C}-16$, the hydroxyl group on $\mathrm{C}-12$, and the carboxyl group on C-4 were deduced from the results of heteronuclear single quantum coherence (HSQC) and heteronuclear multiple bond connectivity (HMBC) experiments. Furthermore, the carbon signals of $4 \mathrm{a}$ were essentially the same as those of ent-12 $\alpha$-angeloyloxykaur-16-en19-oic acid, ${ }^{12)}$ with the exception of the signals due to the angeloyl moiety. Therefore aglycone $\mathbf{4 a}$ was concluded to be ent-12 $\alpha$-hydroxykaur-16-en-19-oic acid.

The ${ }^{13} \mathrm{C}$-NMR spectrum of $\mathbf{4}$ revealed the presence of a terminal $\beta$-apiofuranose and 6-linked $\beta$-glucopyranose determined by the downfield shift of the C-6" ( $\delta$ 67.8), which showed a long-range correlation with the anomeric proton of the $\beta$-apiofuranosyl unit $\left[\delta_{\mathrm{H}} 5.18(\mathrm{~d}, J=2.1 \mathrm{~Hz})\right]$. Furthermore, the chemical shifts of the anomeric proton $(\delta 6.17)$ and that of $\mathrm{C}-1$ ( $\delta 95.5)$ of glucose were characteristic of an ester-linked sugar. In contrast to this, 5 had two terminal $\beta$ glucopyranosyl units. The absolute configuration of $\mathbf{4 a}$ was
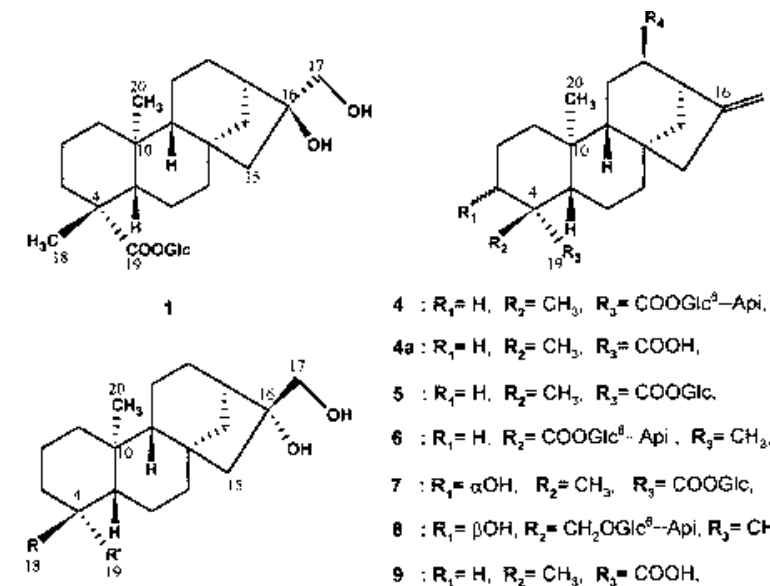

$2: \mathbf{R}=\mathrm{CH}_{3}, \mathbf{R}^{\prime}=\mathrm{COOG} \mid \mathrm{c}$

3: $\mathbf{R}=$ GOOGl: $. \mathbf{R}^{\prime}=\mathrm{CH}_{3}$

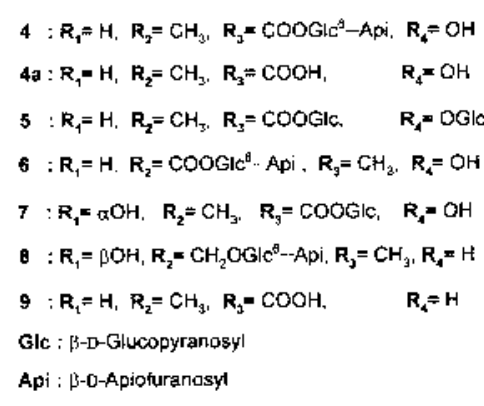

Fig. 1 
Table 1. ${ }^{1} \mathrm{H}-\mathrm{NMR}$ Spectral Data for Compounds 3-5 in Pyridine- $d_{5}(\delta$ in ppm, $400 \mathrm{MHz})$

\begin{tabular}{|c|c|c|c|}
\hline $\mathrm{H}$ & 3 & 4 & 5 \\
\hline $1 \mathrm{a}$ & $1.62(\mathrm{ddd}, 13.1,9.8,3.6)$ & $0.70(\mathrm{ddd}, 12.9,9.8,3.5)$ & $0.63(\mathrm{ddd}, 13.1,9.8,3.6)$ \\
\hline $1 \mathrm{~b}$ & $1.00(\mathrm{brd}, 9.8)$ & $1.63(\mathrm{brd}, 9.8)$ & $1.62(\mathrm{brd}, 9.8)$ \\
\hline $2 \mathrm{a}$ & $1.26(\mathrm{brd}, 13.7)$ & $1.35^{a)}$ & $1.32^{a)}$ \\
\hline $2 b$ & $2.00^{a)}$ & $2.06^{a)}$ & $2.04^{a)}$ \\
\hline $3 a$ & $1.40-1.55^{a)}$ & $2.32(\mathrm{brd}, 13.8)$ & $2.34(\mathrm{brd}, 14.0)$ \\
\hline $3 b$ & $1.95^{a)}$ & $1.00^{a)}$ & $1.01^{a)}$ \\
\hline 5 & $1.92(\mathrm{brd}, 9.8)$ & $1.03(\mathrm{brd}, 9.8)$ & 1.05 (br d, 9.8) \\
\hline $6 a$ & $1.36^{a)}$ & $2.19(\mathrm{brd}, 13.5)$ & $2.32(\mathrm{brd}, 13.5)$ \\
\hline $6 b$ & $1.40-1.55^{a)}$ & $1.95(\mathrm{~m})$ & $1.92(\mathrm{~m})$ \\
\hline $7 \mathrm{a}$ & $1.85(\mathrm{ddd}, 13.7,10.1,4.9)$ & $1.36(\mathrm{ddd}, 13.6,10.1,4.5)$ & $1.39(\mathrm{ddd}, 13.7,10.1,4.9)$ \\
\hline $7 \mathrm{~b}$ & $1.40-1.55^{a)}$ & $1.50(\mathrm{brd}, 13.6)$ & $1.50(\mathrm{brd}, 13.7)$ \\
\hline 9 & $1.14^{a)}$ & $1.00^{a)}$ & $1.01^{a)}$ \\
\hline $11 \mathrm{a}$ & $1.96^{a)}$ & $2.00^{a)}$ & $2.04^{a)}$ \\
\hline $11 \mathrm{~b}$ & $1.40-1.55^{a)}$ & $1.70(\mathrm{~m})$ & $1.70(\mathrm{~m})$ \\
\hline 12 & uncl. $^{b)}$ & $4.11(\mathrm{ddd}, 11.3,6.0,3.1)$ & $4.12(\mathrm{ddd}, 11.5,5.9,3.1)$ \\
\hline 13 & 2.34 (brs) & 2.77 (brs) & 3.15 (brs) \\
\hline $14 \mathrm{a}$ & uncl. $^{b)}$ & $0.95(\mathrm{dd}, 9.8,3.6)$ & $0.96(\mathrm{dd}, 9.7,3.6)$ \\
\hline $14 \mathrm{~b}$ & uncl. $^{b)}$ & $2.06^{a)}$ & $2.06^{a)}$ \\
\hline $15 \mathrm{a}$ & 1.65 (br) & 2.03 (brs) & 2.04 (brs) \\
\hline $15 \mathrm{~b}$ & $1.90-2.09^{a)}$ & 2.03 (brs) & 2.04 (brs) \\
\hline $17 \mathrm{a}$ & $4.01(\mathrm{~d}, 10)$ & 5.20 (brs) & 5.42 (brs) \\
\hline $17 \mathrm{~b}$ & $4.10(\mathrm{~d}, 10)$ & 4.98 (brs) & 4.96 (brs) \\
\hline 18 & & $1.27(\mathrm{~s})$ & $1.24(\mathrm{~s})$ \\
\hline 19 & $0.98(\mathrm{~s})$ & & \\
\hline 20 & $1.32(\mathrm{~s})$ & $1.24(\mathrm{~s})$ & $1.16(\mathrm{~s})$ \\
\hline \multicolumn{4}{|c|}{ 12-Glucosyl } \\
\hline $1^{\prime}$ & & & $4.95(\mathrm{~d}, 7.6)$ \\
\hline \multicolumn{4}{|c|}{ 19-Glucosyl } \\
\hline $1 "$ & $6.30(\mathrm{~d}, 8.3)$ & $6.17(\mathrm{~d}, 8.3)$ & $6.20(\mathrm{~d}, 8.3)$ \\
\hline \multicolumn{4}{|l|}{ Apiosyl } \\
\hline $1^{\prime \prime \prime}$ & & $5.18(\mathrm{~d}, 2.1)$ & \\
\hline
\end{tabular}

a) Overlapping signals. b) uncl., unclear correlation in HSQC.

assigned on the basis of the glycosylation shifts rule. ${ }^{13)}$ Comparison of the ${ }^{13} \mathrm{C}$-NMR spectral data of 5 with those of $4 \mathbf{a}$ revealed a downfield shift of the signal of C-12 (+9.7 ppm) and upfield shift of the signals of $\mathrm{C}-11(-3.0 \mathrm{ppm})$ and $\mathrm{C}-13$ $(-2.3 \mathrm{ppm})$ of 5 . The magnitude of the downfield shift of $\mathrm{C}$ 12 and the upfield shifts of C-11 and -13 caused by $\beta$-D-glucosylation indicated that aglycone $4 \mathbf{a}$ belongs to the ent-series. Thus the structures of $\mathbf{4}$ and $\mathbf{5}$ were assigned as shown.

Compound 6 (cussoracoside $\mathrm{D}, \mathrm{C}_{31} \mathrm{H}_{48} \mathrm{O}_{12}$ ) has the same molecular formula as 4 . The results of HR-FAB-MS as well as the sugars obtained upon acid hydrolysis of $\mathbf{4}$ and $\mathbf{6}$ were the same. On comparison of the ${ }^{13} \mathrm{C}$-NMR data of 6 with those of $\mathbf{4}$, the chemical shifts of signals due to the esterified biose and the aglycone carbons were essentially the same except for the signals due to A-ring carbons. On going from 4 to 6, the chemical shift of C-4 was shifted downfield by +4 ppm while C-1, C-2, C-3, and C-5 were shifted upfield by $-1.6,-1.6,-1.7$, and $-6.3 \mathrm{ppm}$, respectively. These data indicate that the difference between $\mathbf{6}$ and $\mathbf{4}$ is due to the disposition of the methyl groups on the A-ring only. The location of the carboxyl group at C-18 and not at C-19 was confirmed by the observation of an NOE between two methyl proton signals at $\delta 0.89(\mathrm{H}-19)$ and $1.26(\mathrm{H}-20)$ in the NOESY spectrum of $\mathbf{6}$. Thus the structure of compound 6 was determined as shown.

The ${ }^{1} \mathrm{H}$ - and ${ }^{13} \mathrm{C}-\mathrm{NMR}$ spectra of 7 (cussoracoside $\mathrm{E}$, $\mathrm{C}_{26} \mathrm{H}_{40} \mathrm{O}_{9}$ ), which was assigned by $\mathrm{H}-\mathrm{H}$ correlation spectroscopy (COSY), HSQC, and HMBC, showed that the aglycone of 7 is a 12 -hydroxykaur-16-en-18 or -19-oic acid with an additional secondary hydroxyl group located at the 3-position. The $\mathrm{H}-\mathrm{H}$ COSY experiment indicated correlations from H-1 [ $\delta 2.18$ (ddd, $J=12.9,9.8,3.5 \mathrm{~Hz}$ )] to $\mathrm{H}-3$ [ $\delta 3.34$ (dd, $J=12.0,3.9 \mathrm{~Hz}$ )]. In the $\mathrm{HMBC}$ experiment, long-range correlations were observed between the following protons and carbons: $18-\mathrm{H}_{3}$ and 3-, 4-, 5-, 18-C; and 20- $\mathrm{H}_{3}$ and 1-, 5-, 9-, 10-C. Moreover, the fact that the ${ }^{13} \mathrm{C}-\mathrm{NMR}$ spectral data of 7 are very similar to those of ent-3 $\beta$-hydroxykaur-16-en-19-oic acid, ${ }^{14)}$ with respect to the $\mathrm{A}$ - and B-rings led to the location of the carboxyl group at C-19 and the hydroxyl group at C-3. The configuration of the hydroxyl group was concluded to be equatorial from the coupling constant of the carbinyl proton signal $[\delta 3.34(\mathrm{dd}, J=12.0,3.9 \mathrm{~Hz})]$. On alkaline hydrolysis, 7 liberated 1,6-anhydroglucose. These findings led to the formulation of 7 as shown.

The ${ }^{1} \mathrm{H}$ - and ${ }^{13} \mathrm{C}-\mathrm{NMR}$ spectra of $\mathbf{8}$ (cussoracoside $\mathrm{F}$, $\mathrm{C}_{31} \mathrm{H}_{50} \mathrm{O}_{11}$ ) showed the presence of two tertiary methyls $\left[\delta_{\mathrm{C}}\right.$ $\left.12.8,18.3, \delta_{\mathrm{H}} 0.89(3 \mathrm{H}, \mathrm{s}), 0.96(3 \mathrm{H}, \mathrm{s})\right]$, an exocyclic methylene $\left[\delta_{\mathrm{C}} 103.4,155.9, \delta_{\mathrm{H}} 4.80(1 \mathrm{H}\right.$, br s $), 4.87,(1 \mathrm{H}$, br s $\left.)\right]$, an oxygenated methylene group $\left[\delta_{\mathrm{C}} 74.4, \delta_{\mathrm{H}} 3.55(1 \mathrm{H}, \mathrm{d}\right.$, $J=10.5 \mathrm{~Hz}), 4.32(1 \mathrm{H}, \mathrm{d}, J=10.5 \mathrm{~Hz})]$, and a secondary hydroxyl group $\left(\delta_{\mathrm{C}} 72.0\right)$. Comparison of the ${ }^{13} \mathrm{C}$-NMR spectrum of 8 with that of kaurenoic acid $(9)^{8)}$ demonstrated that the signals due to carboxyl $(\delta 179.9)$ and one methylene ( $\delta$ 38.6) of 9 had been replaced by the signal of the oxygenated methylene and the secondary hydroxyl functions in $\mathbf{8}$. These spectral data suggest that the formulation of the aglycone of 8 could be represented as 3,18- or 19-dihydroxykaur-16-ene. The position of these functions was confirmed by an HMBC 
Table 2. ${ }^{1} \mathrm{H}-\mathrm{NMR}$ Spectral Data for Compounds $6-8$ in Pyridine- $d_{5}(\delta$ in ppm, $400 \mathrm{MHz})$

\begin{tabular}{|c|c|c|c|}
\hline $\mathrm{H}$ & 6 & 7 & 8 \\
\hline 1a & $1.60(\mathrm{ddd}, 13.5,9.5,5.0)$ & $2.18(\mathrm{ddd}, 12.9,9.8,3.5)$ & $1.65(\mathrm{ddd}, 13.5,9.5,5.0)$ \\
\hline $1 \mathrm{~b}$ & $1.10(\mathrm{brd}, 9.5)$ & $0.90($ br d, 9.8$)$ & $1.12(\mathrm{brd}, 9.5)$ \\
\hline $2 \mathrm{a}$ & $1.26^{a)}$ & uncl. $^{b)}$ & $1.26^{a)}$ \\
\hline $2 b$ & $0.86^{a)}$ & $1.90(\mathrm{dd}, 12.8,3.9)$ & $0.86^{a)}$ \\
\hline $3 \mathrm{a}$ & $1.55^{a)}$ & $3.34(\mathrm{dd}, 12.0,3.9)$ & \\
\hline $3 b$ & $1.98^{a)}$ & & $4.10(\mathrm{t}, 3.0)$ \\
\hline 5 & $1.92(\mathrm{brd}, 13.5)$ & $1.10(\mathrm{brd}, 9.8)$ & $1.05(\mathrm{brd}, 13.5)$ \\
\hline $6 a$ & $1.38(\mathrm{brd}, 13.5)$ & $2.02(\mathrm{~m})$ & uncl. $^{b)}$ \\
\hline $6 \mathrm{~b}$ & $1.58(\mathrm{~m})$ & uncl $^{a, b)}$ & uncl. $^{b)}$ \\
\hline $7 \mathrm{a}$ & $1.80(\mathrm{ddd}, 13.7,9.8,4.4)$ & $1.40(\mathrm{ddd}, 13.6,10.1,4.5)$ & $1.36(\mathrm{ddd}, 13.7,9.8,4.4)$ \\
\hline $7 \mathrm{~b}$ & $1.49(\mathrm{brd}, 13.7)$ & $1.50(\mathrm{brd}, 13.6)$ & $1.45(\mathrm{brd}, 13.7)$ \\
\hline 9 & $1.12^{a)}$ & $1.00(\mathrm{brd}, 13.6)$ & 0.98 (br d, 13.6) \\
\hline $11 \mathrm{a}$ & $1.98^{a)}$ & uncl. $^{b)}$ & $1.38-1.50^{a)}$ \\
\hline $11 \mathrm{~b}$ & $1.51(\mathrm{~m})$ & uncl. $^{b)}$ & $1.38-1.50^{a)}$ \\
\hline $12 \mathrm{a}$ & $4.05(\mathrm{ddd}, 11.5,5.8,3.0)$ & $4.11(\mathrm{ddd}, 13.0,5.2,3.2)$ & $1.38-1.50^{a)}$ \\
\hline $12 \mathrm{~b}$ & & & $1.38-1.50^{a)}$ \\
\hline 13 & $2.80(\mathrm{br})$ & 2.77 (br) & $2.60(\mathrm{br})$ \\
\hline $14 \mathrm{a}$ & $1.45(\mathrm{dd}, 10.0,3.8)$ & $0.96(\mathrm{dd}, 9.8,3.6)$ & $1.00(\mathrm{dd}, 10.0,3.8)$ \\
\hline $14 \mathrm{~b}$ & $1.90(\mathrm{brd}, 6.4)$ & $2.06(\mathrm{brd}, 9.8)$ & $1.87(\mathrm{brd}, 6.4)$ \\
\hline $15 \mathrm{a}$ & $2.03(\mathrm{brs})$ & $2.10(\mathrm{br})$ & 1.94 (br) \\
\hline $15 b$ & $1.98^{a)}$ & & \\
\hline $17 \mathrm{a}$ & $5.20(\mathrm{brs})$ & $5.20(\mathrm{brs})$ & $4.87(\mathrm{brs})$ \\
\hline $17 b$ & $4.95^{a)}$ & 4.99 (brs) & $4.80(\mathrm{brs})$ \\
\hline $18 \mathrm{a}$ & & $1.63(\mathrm{~s})$ & $3.55(\mathrm{~d}, 10.5)$ \\
\hline $18 \mathrm{~b}$ & & & $4.32(\mathrm{~d}, 10.5)$ \\
\hline 19 & $0.89(\mathrm{~s})$ & & $0.89(\mathrm{~s})$ \\
\hline 20 & $1.26(\mathrm{~s})$ & $1.22(\mathrm{~s})$ & $0.96(\mathrm{~s})$ \\
\hline \multicolumn{4}{|c|}{18 - or 19-Glucosyl } \\
\hline $1 "$ & $6.23(\mathrm{~d}, 8.0)$ & $6.16(\mathrm{~d}, 8.3)$ & $4.79(\mathrm{~d}, 7.8)$ \\
\hline \multicolumn{4}{|l|}{ Apiosyl } \\
\hline $1^{\prime \prime \prime}$ & 5.19 (brs) & & $5.20(\mathrm{~d}, 2.4)$ \\
\hline
\end{tabular}

Assignments based on HSQC. a) Overlapping signals. b) uncl., unclear correlations in HSQC.

experiment with $\mathbf{8}$. The stereochemistry of $\mathrm{C}-3$ and $\mathrm{C}-4$ was deduced as follows. The orientation of the hydroxyl group at C-3 was concluded to be axial from the coupling constant of the $\mathrm{H}-3$ signal $[(\delta 4.10,(1 \mathrm{H}, \mathrm{t}, J=3.0 \mathrm{~Hz})]$. The equatorial orientation of the oxygenated methylene group at C-4 was concluded from observation of a NOE correlation between the two methyl groups on $\mathrm{C}-10(\delta 0.89)$ and C-4 $(\delta 0.96)$.

On acid hydrolysis, 8 afforded glucose and apiose. The ${ }^{1} \mathrm{H}$ and ${ }^{13} \mathrm{C}$-NMR spectra of $\mathbf{8}$ showed the signals due to terminal $\beta$-apiofuranosyl and 6-linked $\beta$-glucopyranosyl moieties. The observation of a $\mathrm{C}-\mathrm{H}$ long-range correlation between the $\mathrm{H}-1(\delta 4.79)$ of glucose and C-18 ( $\delta 74.4)$ of aglycone indicated the presence of the sugar unit at C-18. Based on these results, $\mathbf{8}$ can be formulated as shown.

The ent-nature of cussoracosides $\mathrm{B}$ and $\mathrm{C}$ and the known compounds $\mathbf{1}$ and $\mathbf{2}$ suggests that all the other glycosides also belong to the ent-series. C. racemosa is a new source of sweet glucosides. Since the structure of cussoracoside C is closely related to rubusoside, ${ }^{15}$ a sweet glucoside 115 times as sweet as sucrose, isolated from Rubus suavissimus, its relative sweetness as well as improvement of the quality of sweetness will be the subject of our next investigation.

\section{Experimental}

NMR spectra $\left({ }^{1} \mathrm{H},{ }^{13} \mathrm{C}\right.$, HSQC, HMBC) were recorded in pyridine- $d_{5}$ using a JEOL JNM A-400 spectrometer $\left(400 \mathrm{MHz}\right.$ for ${ }^{1} \mathrm{H}-\mathrm{NMR}$ and $100 \mathrm{MHz}$ for ${ }^{13} \mathrm{C}-\mathrm{NMR}$ ). MS were recorded on a JEOL JMS-SX 102 spectrometer. Optical rotations were measured with a Union PM-1 digital polarimeter. Preparative HPLC was carried out on columns of ODS $(150 \times 20 \mathrm{~mm}$ i.d., YMC) with a Tosoh refraction index (RI-8) detector, flow rate $6 \mathrm{ml} / \mathrm{min}$. For column chromatography, silica gel G 60 (Merck), RP-18 (50 mm, YMC) and a highly porous copolymer of styrene and divinylbenzene (Mitsubishi Chemical Industries) were used. The solvent systems were: (I) $\mathrm{CH}_{2} \mathrm{Cl}_{2}-$ $\mathrm{MeOH}-\mathrm{H}_{2} \mathrm{O}$ (17: $4: 0.5$ to $17: 8: 2$ ); (II) $20-100 \% \mathrm{MeOH}$; and (III) $30 \%$ $\mathrm{CH}_{3} \mathrm{CN}$. The spray reagent used for TLC was $10 \% \mathrm{H}_{2} \mathrm{SO}_{4} \mathrm{O}$ in $50 \% \mathrm{EtOH}$

Plant Material Plant material was collected in March 2000 from Ranomafana-Ifanadiana, Madagascar. The identity of the plant was confirmed by Dr. Armand Rakotozafy from the Institut Malgache de Recherches Appliquées.

Extraction and Isolation The dried leaves $(1.750 \mathrm{~kg})$ of $C$. racemosa were extracted with $\mathrm{MeOH}$. After removal of the solvent by evaporation, the residue $(362.7 \mathrm{~g})$ was suspended in water and extracted with hexane and EtOAc in succession. The aqueous layer $(253.0 \mathrm{~g})$ was subjected to a column of a highly porous copolymer of styrene and divinylbenzene, and eluted successively with $\mathrm{H}_{2} \mathrm{O}, 30 \% \mathrm{MeOH}, 100 \% \mathrm{MeOH}$, and $\mathrm{Me}_{2} \mathrm{CO}$. The fraction eluted with $\mathrm{MeOH}$ was chromatographed on a column of silica gel (system I), affording eight fractions. Fractions 1 and 2 were subjected to chromatography on RP-18 and a ODS-HPLC using system II and system III, respectively, to afford compounds $\mathbf{1}(85 \mathrm{mg}), \mathbf{2}(80 \mathrm{mg}), \mathbf{3}(15 \mathrm{mg}), \mathbf{4}(104 \mathrm{mg}), \mathbf{5}$ (196 mg), 6 (7 mg), 7 (12 mg), 8 (11 mg).

Acid Hydrolysis of 4, 6, and 8 Each sample $(10 \mathrm{mg}$ of 4, $3 \mathrm{mg}$ of $\mathbf{6}$, $5 \mathrm{mg}$ of 8 ) was dissolved in $10 \% \mathrm{H}_{2} \mathrm{SO}_{4}$, and refluxed for $2 \mathrm{~h}$. The reaction mixture was cooled and extracted with EtOAc. The aqueous layer was examined for sugar by direct comparison on silica gel TLC with authentic glucose and apiose.

Alkaline Hydrolysis of 3, 4, and 7 A solution of each compound [3 $(5 \mathrm{mg}), 4(50 \mathrm{mg}), 7(5 \mathrm{mg})]$ in $1 \mathrm{~N} \mathrm{KOH}-\mathrm{MeOH}$ was refluxed for $1 \mathrm{~h}$. The reaction mixture was cooled and extracted with EtOAc. The produced aglycone was identified by ${ }^{1} \mathrm{H}$ - and ${ }^{13} \mathrm{C}$-NMR spectra. The aqueous layer (from 3, 7) was examined for sugar by direct comparison on silica gel TLC with authentic 1,6-anhydroglucose.

3: $[\alpha]_{\mathrm{D}}^{19}-37.6^{\circ}(c=0.1, \mathrm{MeOH}) ;{ }^{1} \mathrm{H}-\mathrm{NMR}$ : Table $1 ;{ }^{13} \mathrm{C}-\mathrm{NMR}$ : Table 3; negative HR-FAB-MS, $m / z$ : $497.2783[\mathrm{M}-\mathrm{H}]^{-}\left(\mathrm{C}_{26} \mathrm{H}_{41} \mathrm{O}_{9}\right.$ requires 497.2750).

4: $[\alpha]_{\mathrm{D}}^{19}-27.2^{\circ}(c=0.5, \mathrm{MeOH}) ;{ }^{1} \mathrm{H}-\mathrm{NMR}$ : Table $1 ;{ }^{13} \mathrm{C}-\mathrm{NMR}$ : Table 
Table 3. ${ }^{13} \mathrm{C}-\mathrm{NMR}$ Spectral Data for Compounds $2-9$ in Pyridine- $d_{5}(\delta$ in ppm, $100 \mathrm{MHz}$ )

\begin{tabular}{|c|c|c|c|c|c|c|c|c|c|}
\hline C & 2 & 3 & $4 a$ & 4 & 5 & 6 & 7 & 8 & 9 \\
\hline 1 & 40.9 & 37.7 & 40.5 & 40.6 & 40.6 & 39.0 & 38.8 & 38.7 & 41.1 \\
\hline 2 & 19.5 & 17.9 & 19.7 & 19.5 & 19.5 & 17.9 & 28.7 & 27.2 & 19.8 \\
\hline 3 & 38.5 & 36.8 & 38.5 & 38.2 & 38.3 & 36.5 & 78.2 & 72.0 & 38.6 \\
\hline 4 & 44.2 & 48.0 & 44.0 & 44.0 & 44.1 & 48.0 & 49.8 & 43.0 & 43.8 \\
\hline 5 & 57.5 & 50.3 & 56.3 & 56.3 & 56.0 & 50.0 & 56.3 & 47.5 & 55.2 \\
\hline 6 & 22.6 & 23.6 & 22.4 & 22.1 & 22.1 & 23.0 & 21.8 & 20.1 & 22.5 \\
\hline 7 & 42.8 & 41.8 & 40.9 & 40.8 & 40.4 & 39.2 & 40.4 & 40.7 & 41.5 \\
\hline 8 & 44.9 & 44.9 & 44.0 & 44.1 & 43.8 & 44.0 & 43.7 & 44.1 & 44.4 \\
\hline 9 & 56.3 & 56.9 & 56.7 & 57.1 & 57.1 & 57.1 & 56.6 & 55.6 & 57.1 \\
\hline 10 & 40.1 & 38.9 & 39.4 & 39.5 & 39.4 & 38.3 & 39.1 & 39.0 & 39.9 \\
\hline 11 & 19.0 & 18.4 & 29.3 & 29.4 & 26.3 & 28.9 & 29.4 & 18.3 & 18.6 \\
\hline 12 & 26.7 & 26.7 & 71.2 & 71.2 & 80.9 & 71.2 & 71.0 & 33.3 & 33.3 \\
\hline 13 & 45.9 & 46.0 & 51.9 & 51.9 & 49.6 & 51.9 & 51.8 & 44.2 & 44.2 \\
\hline 14 & 37.6 & 39.5 & 39.0 & 39.8 & 38.8 & 39.6 & 39.5 & 39.8 & 39.9 \\
\hline 15 & 53.7 & 53.8 & 49.4 & 49.4 & 49.4 & 49.3 & 49.1 & 49.1 & 49.2 \\
\hline 16 & 81.7 & 81.6 & 150.9 & 151.0 & 150.1 & 150.7 & 150.8 & 155.9 & 155.7 \\
\hline 17 & 66.5 & 66.4 & 106.4 & 106.3 & 107.6 & 106.4 & 106.4 & 103.4 & 103.5 \\
\hline 18 & 28.6 & 177.7 & 29.3 & 28.6 & 28.5 & 177.6 & 24.2 & 74.4 & - 29.3 \\
\hline 19 & 176.9 & 18.3 & 180.0 & 176.7 & 176.8 & 18.2 & 176.3 & 12.8 & 179.9 \\
\hline 20 & 15.9 & 16.8 & 16.3 & 16.3 & 16.2 & 16.8 & 16.0 & 18.3 & 16.0 \\
\hline \multicolumn{10}{|c|}{$12-O-\mathrm{Glc}$} \\
\hline $1^{\prime}$ & & & & & 104.4 & & & & \\
\hline $2^{\prime}$ & & & & & 75.3 & & & & \\
\hline $3^{\prime}$ & & & & & 78.5 & & & & \\
\hline $4^{\prime}$ & & & & & 71.7 & & & & \\
\hline $5^{\prime}$ & & & & & 78.2 & & & & \\
\hline $6^{\prime}$ & & & & & 62.9 & & & & \\
\hline \multicolumn{10}{|c|}{18 - or $19-O-\mathrm{Glc}$} \\
\hline $1^{\prime \prime}$ & 95.8 & 96.1 & & 95.5 & 95.8 & 96.0 & 95.9 & 105.3 & \\
\hline $2^{\prime \prime}$ & 74.1 & 74.3 & & 73.9 & 74.0 & 74.2 & 73.9 & 74.8 & \\
\hline $3^{\prime \prime}$ & 79.3 & 79.5 & & 79.0 & 79.3 & 78.8 & 79.5 & 78.5 & \\
\hline $4^{\prime \prime}$ & 71.2 & 71.0 & & 71.1 & 71.0 & 71.0 & 70.8 & 72.0 & \\
\hline $5^{\prime \prime}$ & 79.3 & 78.9 & & 77.6 & 79.1 & 77.6 & 78.9 & 76.9 & \\
\hline $6^{\prime \prime}$ & 62.2 & 62.1 & & 67.8 & 62.1 & 68.0 & 61.8 & 69.1 & \\
\hline \multicolumn{10}{|l|}{ Api } \\
\hline $1^{\prime \prime \prime}$ & & & & 110.8 & & 110.9 & & 111.1 & \\
\hline $2^{\prime \prime \prime}$ & & & & 77.9 & & 77.9 & & 77.6 & \\
\hline $3^{\prime \prime \prime}$ & & & & 80.4 & & 80.4 & & 80.4 & \\
\hline $4^{\prime \prime \prime}$ & & & & 75.1 & & 75.1 & & 75.0 & \\
\hline $5^{\prime \prime \prime}$ & & & & 65.8 & & 65.8 & & 65.5 & \\
\hline
\end{tabular}

Glc, $\beta$-D-glucopyranosyl; Api, $\beta$-D-apiofuranosyl.

3; negative HR-FAB-MS, $m / z: 611.3071[\mathrm{M}-\mathrm{H}]^{-}\left(\mathrm{C}_{31} \mathrm{H}_{47} \mathrm{O}_{12}\right.$ requires 611.3067)

4a $(15 \mathrm{mg}):[\alpha]_{\mathrm{D}}^{19}-55.0^{\circ}(c=0.2, \mathrm{MeOH})$; negative HR-FAB-MS, $m / z$ : $317.2107[\mathrm{M}-\mathrm{H}]^{-}\left(\mathrm{C}_{20} \mathrm{H}_{29} \mathrm{O}_{3}\right.$ requires 317.2117$) .{ }^{1} \mathrm{H}-\mathrm{NMR}$ spectral data (pyridine- $\left.d_{5}\right): \delta 5.19(1 \mathrm{H}$, br s, H-17a), $4.98(1 \mathrm{H}, \mathrm{brs}, \mathrm{H}-17 \mathrm{~b}), 4.00(1 \mathrm{H}$, ddd, $J=11.5,6.0,3.1 \mathrm{H}-12), 2.78(1 \mathrm{H}$, br s, $\mathrm{H}-13), 2.40(1 \mathrm{H}, \mathrm{br}$ d, $J=13.8$ H-3), $2.08(2 \mathrm{H}$, br s, H-15a, H-15b), $1.80(1 \mathrm{H}$, br d, $J=13.6 \mathrm{H}-7 \mathrm{a}), 1.28(3 \mathrm{H}$, s, H-18), 1.07 (3H, s, H-20); ${ }^{13} \mathrm{C}-\mathrm{NMR}$ : Table 3.

5: Amorphous powder $[\alpha]_{\mathrm{D}}^{19}-30.0^{\circ}(c=0.5, \mathrm{MeOH}) ;{ }^{1} \mathrm{H}-\mathrm{NMR}$ : Table 1; ${ }^{13} \mathrm{C}-\mathrm{NMR}:$ Table 3; negative HR-FAB-MS, $m / z$ : $641.3166[\mathrm{M}-\mathrm{H}]^{-}$ $\left(\mathrm{C}_{32} \mathrm{H}_{49} \mathrm{O}_{13}\right.$ requires 641.3172).

Enzymatic Hydrolysis of 5 An aqueous solution of $5(56 \mathrm{mg})$ and crude hesperidinase was incubated at $37^{\circ} \mathrm{C}$ for $72 \mathrm{~h}$. The solution was extracted with EtOAc and the produced aglycone was identified as $\mathbf{4 a}$ by comparison of its spectral data.

6: $[\alpha]_{\mathrm{D}}^{19}-19.5^{\circ}(c=0.5, \mathrm{MeOH}) ;{ }^{1} \mathrm{H}-\mathrm{NMR}$ : Table $2 ;{ }^{13} \mathrm{C}-\mathrm{NMR}$ : Table 3; negative HR-FAB-MS, m/z: $611.3079[\mathrm{M}-\mathrm{H}]^{-}\left(\mathrm{C}_{31} \mathrm{H}_{47} \mathrm{O}_{12}\right.$ requires 611.3067)

7: $[\alpha]_{\mathrm{D}}^{19}-30.5^{\circ}(c=1.6, \mathrm{MeOH}) ;{ }^{1} \mathrm{H}-\mathrm{NMR}$ : Table $2 ;{ }^{13} \mathrm{C}-\mathrm{NMR}$ : Table 3; negative HR-FAB-MS, $m / z: 495.2600[\mathrm{M}-\mathrm{H}]^{-}\left(\mathrm{C}_{26} \mathrm{H}_{39} \mathrm{O}_{9}\right.$ requires 495.2593).

8: $[\alpha]_{\mathrm{D}}^{19}-35.7^{\circ}(c=0.4, \mathrm{MeOH}) ;{ }^{1} \mathrm{H}-\mathrm{NMR}$ : Table $2 ;{ }^{13} \mathrm{C}-\mathrm{NMR}$ : Table 3 ; negative HR-FAB-MS, $m / z$ : $597.3276[\mathrm{M}-\mathrm{H}]^{-}\left(\mathrm{C}_{31} \mathrm{H}_{49} \mathrm{O}_{11}\right.$ requires 597.3274)

Preliminary Test of Sweetness The sweet taste of cussoracoside C and the bitter taste of cussoracoside B were determined by a human sensor.

Acknowledgment Liva Rakotondraibe Romuald Harinantenaina is grateful to the Japanese Ministry of Education, Science, Culture and Sport for the award of a scholarship to study for a Ph.D. at the Institute of Pharmaceutical Sciences, Hiroshima University, Japan. We also thank the Research Center for Molecular Medicine, Hiroshima University School of Medicine, Japan, for the use of its facilities.

References

1) Mabberley D. J., "The Plant-Book, a Portable Dictionary of the Higher Plants," Cambridge University Press, 1987, pp. 449-450.

2) Samyn J.-M., "Plantes Utiles des Hautes Terres de Madagascar," Graphoprint, Madagascar, 1999, p. 16

3) Dubois M. A., Ilyas M., Wagner H., Planta Med., 2, 80-83 (1986).

4) Gunzinger J., Msonthi J. D., Hostettmann K., Phytochemistry, 25, 2501-2503 (1986).

5) Papajewski S., Guse J.-H., Roos G., Sussmuth R., Volger B., Walter C. U., Kraus W., Planta Med., 64, 479-481 (1998).

6) Wollenweber E., Doerr M., Siems K., Faure R., Bombarda I., Gaydou E. M., Biochem. Systematics Ecol., 27, 103-105 (1999).

7) Chazan J. B., Phytochemistry, 10, 2111-2116 (1971).

8) Cheng D. L., Cao X. P., Wei H. X., He L., Phytochemistry, 33, 11811183 (1993).

9) Yamasaki K., Kohda H., Kobayashi T., Kaneda N., Kasai R., Tanaka O., Nishi K., Chem. Pharm. Bull., 25, 2895-2899 (1977).

10) Kaneda N., Kohda H., Yamasaki K., Tanaka O., Nishi K., Chem. Pharm. Bull., 26, 2266-2267 (1978).

11) Mossetig E., Beglinger U., Dolder F., Lichiti H., Quitt P., Walters J. A., J. Am. Chem. Soc., 85, 2305-2309 (1963).

12) Gutiérrez A. B., Werner H., Phytochemistry, 29, 1937-1940 (1990).

13) Kasai R., Suzuo M., Asakawa J., Tanaka O., Tetrahedron Lett., 1977 $175-178$.

14) Lunnon M. W., MacMillan J., Phinney B. O., J. Chem. Soc. Perkin Trans. 1, 1977, 2308-2316.

15) Tanaka T., Kohda H., Tanaka O., Chen F. H., Chou W. H., Leu J.-L., Agric. Biol. Chem., 45, 2165-2166 (1981). 